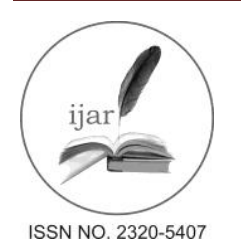

\section{Journal homepage:http://www.journalijar.com \\ Journal DOI:10.21474/IJAR01}

\section{RESEARCH ARTICLE}

\title{
KNOWLEDGE REGARDING SELECTED POSTNATAL BREAST PROBLEMS AND THEIR MANAGEMENT AMONG POSTNATAL MOTHERS.
}

\section{Anjali Pushkar Tiwari ${ }^{1}$,Patel VaishakhiPareshbhai ${ }^{2}$ and Patel Bhakti Rajendrakumar ${ }^{3}$.}

1. Assistant Professor\& HOD, Dept. of Obstetrics \&Gynaecological Nursing, Manikaka Topawala Institute of Nursing, CHARUSAT, Gujarat.

2. Final year B.Sc Nursing Student, Manikaka Topawala Institute of Nursing, CHARUSAT, Gujarat.

3. Final year B.Sc Nursing Student, Manikaka Topawala Institute of Nursing, CHARUSAT, Gujarat.

\section{Manuscript Info Abstract}

\section{Manuscript History:}

Received: 19 March 2016

Final Accepted: 10 April 2016

Published Online: May 2016

Key words:

Knowledge, postnatal mothers, postnatal breast problems, postnatal services.

*Corresponding Author

Anjali PushkarTiwari.
Mothers' contribution in creating a healthy population is beyond explanation. After a woman has safely negotiated the physiologic hardship of pregnancy and labour, the time comes for her body to start to adjust to the new bodily changes as well as try to revert back to the pre-pregnant state. During this period if a woman does not pay attention to the bodily needs, then it can lead to various health issues, some of which can even have an everlasting effect on life.

Among the various health issues are the ones related to the breast changes like breast engorgement, plugged milk duct, breast infection, insufficient milk supply, cracked nipples and sore nipples. Mothers after delivery tend to either neglect their care or lack adequate knowledge regardingpostnatal breast problems leading them to develop severe complication at times.

Thus the present study was done to assess the knowledge of postnatal mothers regarding selected postnatal breast problems and their management. A non-experimental descriptive design was adopted. Data collection was done using a structured knowledge questionnairefrom 60 conveniently selected postnatal mothersattending the postnatal services at Vadilal Sarabhai Hospital, Ahmedabad. The results revealed that majority of the postnatal mothers had inadequate/poor knowledgeregarding selected postnatal breast problems and their management whereas only $30 \%$ of themhad adequate knowledge.

Copy Right, IJAR, 2016.. All rights reserved.

\section{Introduction:-}

In all societies, the family is the central bond for the people, their lives, their dreams and their health. A women in her role as a mother forms the back bone of the family. Pregnancy and child birth are events that touch nearly every aspect of the human experience- biological, psychological, social and cultural. Pregnancy is associated with several physiological and psychological changes which at times might prove to be disturbing and distressing. After a woman has safely negotiated the physiologic hardship of pregnancy and labour, her body has to adjust to the new bodily changes as well as try to revert back to the pre-pregnant state. These bodily changes occur due to the enormous hormonal changes that takes place during the pregnancy and postnatal period.

Among these various bodily changes are the changes that occur in breast as well. This causes increased blood flow, changes in the breast tissues which make it at times sore, tingly, and swollen. Among the various breast problems arising due to the hormonal changes in the body are breast engorgement, plugged milk duct, breast infection, insufficient milk supply, cracked nipples, sore nipplesand deep breast pain secondary to inefficient milk removal. 
These breast problems are rampantly present in postnatal mothers. Usually if proper care is not taken, mothers get affected with these breast problems within 3-5 days of postnatal period. Minor breast problems are not life threatening. A minor problem may escalate and become serious complication of postnatal period. Following faulty breast feeding techniques, ignorance of mother regarding feeding practices, improper breast hygiene, lack of proper health education, cultural beliefs and practices during postnatal period forces mothers to neglect proper breast feeding techniques and breast care. This negligence and ignorance leads to exaggerate and in turn leads to suppression of lactation.

According to a study conducted on 600 postnatal mothers at Allahbad, India to know the complication associated with breast in the post-natal period and to promote early breast feeding and to teach advantages of demand feeding, it was found that $43.33 \%$ of the postnatal mothers had breast engorgement, $15.83 \%$ had cracked nipples, $10 \%$ had retracted nipples, $8.3 \%$ had cracked\& sore nipples, $7.5 \%$ had lactation failure and 3.33\% had breast abscess $/ \mathrm{mastitis}$.

Several such studies have reported the high prevalence of post-natal breast problem and the major cause of it to be the lack of knowledge of mothers and their ignorance regarding the same. Even the postnatal mothers have been ignorant of the various methods of managing the postnatal breast problems. Thusthe investigators felt the primarily need to assess the knowledge of postnatal mothers regarding postnatal breast problems and their management in order to effectively manage the same.

\section{Materials and methods:-}

This was a non-experimental descriptive study carried out among 60 postnatal mothers who attended the postnatal services at Vadilal Sarabhai Hospital, Ahmedabad. They were selected using convenient sampling technique. Data collection was done by usingdemographic proforma and structured knowledge questionnaire. Thecontent validity of the research tool was established with thehelp of experts from the related field. Reliability of the tool wasestablished by using Split Half method. The tool was found reliable ( $\mathrm{r}=0.98)$ to measure knowledge regarding postnatal breast problems and its management.The investigator obtained permission from therespective authority of the hospital. Data collection was done after obtaining informed consentfrom the participants. The data were analyzed by usingboth descriptive and inferential statistics.

\section{Result:-}

Demographic characteristics of postnatal mothers:-

The findings of the study revealed that $58.3 \%$ samples belonged to the age group of $20-24$ years, whereas $28.3 \%$ belonged to the age group of 25-29 years. Majority of samples $66.7 \%$ belonged to Muslim religion, $73.4 \%$ had primary education and $91.7 \%$ were housewives. $71.4 \%$ samples belonged to joint family and $81.7 \%$ belonged to urban community. In regards to the number of previous pregnancies, $48.4 \%$ samples had 1 previous pregnancy and $31.7 \%$ samples had 2 previous pregnancies.

Level of knowledge regarding selected postnatal breast problems and their management:-

The findings of the present study revealed that a massive $30 \%$ and $40 \%$ of the participants had inadequate and only average knowledge regarding postnatal breast problems and their management, respectively. The mean knowledgescore of the postnatal mothers was 21.16 \pm 2.73 . Detail information is displayed in Table 1.

Table 1: Frequency and percentage distribution of knowledge scores of postnatal mothers regarding selected postnatal breast problems and their management.

\begin{tabular}{|c|c|c|c|c|c|c|}
\hline $\begin{array}{l}\text { Sr. } \\
\text { No. }\end{array}$ & Level of knowledge & Scores & Frequency & Percentage & $\begin{array}{l}\text { Mean } \\
\text { score }\end{array}$ & $\begin{array}{l}\text { Standard } \\
\text { deviation }\end{array}$ \\
\hline 1. & Inadequate & 25 to 28 & 18 & 30 & \multirow{3}{*}{21.16} & \multirow{3}{*}{2.73} \\
\hline 2. & Average & 19 to 24 & 24 & 40 & & \\
\hline 3. & Adequate & Less than 19 & 18 & 30 & & \\
\hline
\end{tabular}


Association between knowledge regarding selected postnatal breast problems and their management with socio-demographic variables of participants:-

Analysis of the association between the level of knowledgeregarding postnatal breast problems and their management among postnatal mothers and theirselected variables revealed that the variables age in years, religion, education, occupation, type of community, type of family, monthly income (in Indian rupees) and number of previous pregnancy in relation with knowledge scores of Postnatal mothers were independent of each other (all $\mathrm{p}$ values $>0.05$ ). There was no significant associationbetween the knowledge score and any of the selected sociodemographic variables.

\section{Discussion:-}

In the present study, findings related to knowledge scores showed that a massive $30 \%$ and $40 \%$ of the participants had inadequate and only average knowledge regarding postnatal breast problems and their management, respectively, whereas only $30 \%$ had good knowledge each regarding the same. A similar finding was reported in a study done by HadijahMbwana (2012) where 64\% mothers had average knowledge regarding management of postnatal breast problems in postnatal mothers. One of the reasons for knowledge scores of the participants of both of the studies falling in average range may be due to the lack of proper previous exposure \& education about selected postnatal breast problems and their management.

In present study analysis was done for identifying association between knowledge and selected socio-demographic variables by computing chi-square test. The study findings showed that there was no significant relationship between age in years and knowledge scores of postnatal mothers regarding selected postnatal mothers and their management.Similar finding was seen in a study conducted by LucenAfrose and et al (2012), which showed that there was no significant relationship between age in years and knowledge scores regarding management of postnatal breast problems in postnatal mothers.

\section{Conclusion:-}

The findings of the study illustrated that only nominal number of postnatal mothers had adequate knowledge on postnatal breast problems and their management which indicated that there was stilllack of adequate knowledge. Thus, health education programsare required to enhance the knowledge regarding postnatal breastproblems, proper breast feeding techniques and breast care to create awareness among postnatalmothers as well as antenatal mothers which may further help to reduce breast problems inpostnatal period. Awareness regarding management of postnatal breast problems can be planned to improve knowledge among nursing students, staffs and other health personnel (ASHA, Anganwadi worker, ANM) so it can help to improve knowledge among community people through these health personnel.

\section{Reference:-}

1. Liji J, Malita P C, Manjima M.G, Reshma G. (2015) Knowledge regarding breast problems among Antenatal mothers in a selected hospital, Mangaluru with a view to develop an information booklet. International Journal of Recent ScientificResearch. 6(9):6228-31. Available from: http://www.recentscientific.com/sites/default/files/3413.pdf

2. Poreddi V, SusheelaT, Mythili D. (2015) Knowledge, attitudes and breast feeding practices of postnatal mothers: A cross sectional survey. International Journal of Health Sciences. 9(4):364-74. Available : http://www.ncbi.nlm.nih.gov/pmc/articles/PMC4682591/

3. Ganguli G, Dhavan N, Mukherji K, Dayal M, Pandey RC. (1999) Prevention and management of postnatal breast complications. The journal of obstetrics and gynecology of India. 49(2): 47-49.

4. Pavithra E, Poojamol K, Veena J. (2015) A study to assess effect of structured teaching programme on the prevention and management of breast engorgement among the postnatal mothers admitted in the postnatal ward, in a selected tertiary hospital, Kanchipuram district, Tamil Nadu. International Journal of scientific research. 4(9): 100-1. Available from: http://www.worldwidejournals.com/ijsr/file.php?val=September_2015_1457190388_133.pdf

5. Alden K, Lowdermilk D, Cashion M, Perry S. (2011) Maternity and women's health care. 10th edition. St.Louis Missouri: Mosby publications.

6. Bushra M, Lamia D. (2011) Breast Feeding Problems in Primipara Mothers in Early Postnatal Period. Iraqi Journal of Community Medicine. 24(3): 192-5. Available from: http://www.iasj.net/iasj?func=fulltext\&aId=59449 
7. Madhu K, Sriram C, Ramesh M. (2009) Breast Feeding Practices and Newborn Care in Rural Areas: A Descriptive Cross-Sectional Study. Indian J Community Med. 34(3): 243-6. Available from: www.ncbi.nlm.nih.gov/pmc/articles/PMC2800906

8. Amarasena S. (2008) Incidence of breast and nipple abnormalities among primigravid women in Sri Lanka. Sri Lanka Journal of Child Health.35(2): 51-54. Available from: http://doi.org/10.4038/sljch.v35i2.14

9. Susan A Orshan. (2008) Maternity, newborns and women's health nursing: Comprehensive care across the life span. 1st edition.Philadelphia: Lippincott Williams and Wilkins.

10. Hadijah Ally Mbwana. (2012) A study on exclusive breast feeding mothers awareness and healthcare providers practices during antenatal visits at Morogo, Tanzania, New Zealand". Available from: mro.massey.ac.nz/bitstream/handle/10179/3863/02_whole.pdf

11. LucenAfrose et al. (2012) Factors associated with knowledge about breast feeding among female garment workers in Dhaka city. WHO South-East Asia Journal of public Health. 1(3):249-55. Available from: http://www.Searo. Who.int/publications/journals 